\title{
Species diversity of zooplankton in the Argun River basin in 2018
}

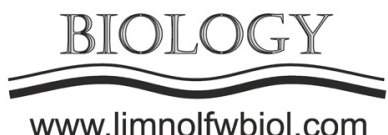

\author{
Zykova E.H. ${ }^{1,2}$ \\ ${ }^{1}$ Eastern Branch of Russian Research Institute for Integrated Water Management and Protection (RosNIIVH) \\ ${ }^{2}$ Department of Water Management and Engineering Ecology, Transbaikal State University, Alexandro-Zavodskaya Str. 30, Chita, \\ 672039, Russia
}

\begin{abstract}
In 2018, 107 species, subspecies, and generic names were found in the zooplankton of the Argun River basin; the number of Cladocera was 52, Rotifera - 43, and Copepoda - 12. Planktofauna was characterized by high species richness due to the basin location in the Amur transitional zoogeographic region and diverse natural conditions in the area. Species that are rare in the Zabaikalsky Krai and Russia were found. According to the data from the observation stations, the number of species varied significantly in the Argun River basin and its tributaries. Species diversity index varied from 1.75 to 3.87 bits / copy. The number of species decreased in the Argun River basin with distance from the upper section, which is a very swampy floodplain.
\end{abstract}

Keywords: Zooplankton, species richness, the Argun River and tributaries

\section{Introduction}

Studying the biodiversity in water communities of the transboundary Argun River basin possessing specific characteristics of its zoogeographic location and various biomes is of scientific interest and a very important issue of environmental protection.

\section{Material and methods}

The rotifers and lower crustaceans collection sampled in the area of the Argun River (11 observation stations) and its tributaries (the Mutnaya, the Urulyungui, the Verhnaya Borzya, the Srednaya Borzya, the Nizhnaya Borzya, the Malaya Kilga river valley, the Kamara, and the Urov) on August 18-22, 2018, served as the material for the research. Collection and quantitative and qualitative processing of samples were carried out in compliance with common methods used in Hydrobiology (Metodicheskiye rekomendatsii..., 1984).

\section{Results and discussion}

In 2018, the planktofauna species list of the Argun River and its tributaries comprised 107 representatives of species, subspecies and generic ranks. The Argun River basin was characterized by a high level of species richness. The species identified belonged to 52 genera, 22 families, 11 orders, and 4 classes.
Branched crustaceans were distinguished by the highest species richness, i.e. by 52 species; rotifers were represented by 43 species and subspecies forms; 12 species of oar-footed crustaceans were identified. The most diverse families were the Cladocera Chydoridae (24 species from 15 genera), the rotifer Brachionidae (16 species and varieties from 4 genera), and the copepod Cyclopidae (10 species from 8 genera).

In accordance with zoogeographic characteristics, the vast majority of rotifer species (78 \%) belonged to cosmopolitan species; Holarctic species accounted for 9 $\%$, Palearctic $-2 \%$, those belonging to other areas -4 $\%$, and species with an unspecified distribution $-7 \%$.

Based on A. A. Kotov's classification (2016), species of branched crustaceans belonged to the following faunal complexes: unrevised widespread species $-40 \%$, southern thermophilic complex $-22 \%$, widespread Eurasian faunal complex $-20 \%$, endemic East Asian complex-11 \%, and species, for which distribution area was not precisely established $-8 \%$.

Among copepod species, cosmopolitans accounted for $47 \%$, Palearctic species - $20 \%$, those of narrower distribution (Eastern Siberia, the Far East) $-13 \%$, and those, for which distribution area was not precisely established $-20 \%$.

Most species were widespread; species endemic in the East Asian complex and rare in Russia were found in the Zabaikalsky Krai for the first time (Neretina et al., 2019; Zykova and Neretina, 2019;).

In the planktofauna of the Argun River, 85 species

*Corresponding author.

E-mail address: evgenia.zykova@mail.ru (E. H. Zykova)

(C) Author(s) 2020. This work is distributed under the Creative Commons Attribution 4.0 License. 
were found, comprising 31 rotifers, 43 cladocerans, and 11 copepods. According to observation stations data, the number of species varied significantly ranging from 4 to 32 . Species diversity index varied from 1.75 to 3.87 bits / copy.

In the Argun River tributaries, the total number of species was 77, including 32 rotifers, 35 cladocerans, and 10 copepods. The number of species varied in the tributaries from 4 to 37. The Mutnaya and Urulyungui rivers were the richest in species. Species diversity index varied from 1.89 to 3.64 bits / copy.

\section{Conclusions}

The zooplankton in the streams of the Argun River basin was characterized by high species richness due to the basin location in the Amur transitional zoogeographic region and diverse natural conditions in the area. In 2018, 107 species, subspecies, and generic names were found in zooplankton.

According to data from the observation stations, the number of species varied significantly in the Argun River basin and its tributaries. The number of species decreased in the Argun River basin with distance from the upper section, which is a very swampy floodplain.

\section{Acknowledgements}

The author would like to express her deepest appreciation to the following staff of the A.N. Severtsov Institute for Ecology and Evolution RAS: A.A. Kotov D.Sc. in Biology, A. Yu. Sinev D.Sc. in Biology, N.M.
Korovchinsky D.Sc. in Biology, and A.N. Neretina Cand. Sc. in Biology for the assistance in identifying rare species of Cladocera as well as to thank the colleague N.G. Sheveleva Cand.Sc. in Biology from Limnological Institute SB RAS for assistance in identifying species of Copepoda.

This research was partially supported by the ZabGU grant No. 300-GR.

\section{References}

Zykova E.H., Neretina A.N. 2019. The first find of Ceriodaphnia cf. cornuta (Crustacea: Cladocera) in the Argun River Basin (Transbaikal region). In: VIII All-Russian Conference "Readings in Memory of Professor V. Ya. Levanidov", p. 36. (in Russian)

Kotov A.A. 2016. Faunistic complexes of Cladocera (Crustacea, Branchiopoda) of Eastern Siberia and the Far East of Russia. Biology Bulletin 43: 970-987. DOI: 10.1134/ S1062359016090041

Metodicheskiye rekomendatsii po sboru i obrabotke materialov pri gidrobiologicheskikh issledovaniyakh na presnovodnykh vodoyemakh. Zooplankton i yego produktsiya [Guidelines for the collection and processing of materials in hydrobiological studies in freshwater bodies. Zooplankton and its products]. 1984. In: Vinberg G.G., Lavrent'yeva G.M. (Eds.). Leningrad: GosNIORH. (in Russian)

Neretina A.N., Zykova E.H., Garibian P.G. et al. 2019. A review of interesting records of water fleas (Crustacea: Claudocera) in the water bodies of the Transbaikal region and some adjacent areas. In: International Conference dedicated to the 50th anniversary of the Joint Russian-Mongolian Complex Biological Expedition of RAS and ANM, pp. 152-155. (in Russian) 